\title{
EDUKASI KESEHATAN TERKAIT UPAYA SWAMEDIKASI PENYAKIT OSTEOARTHRITIS PADA LANSIA
}

\author{
Rea Ariyanti ${ }^{1)}$, Nanta Sigit ${ }^{1)}$, Luluk Anisyah ${ }^{1)}$ \\ 1)Sarjana Terapan Manajemen Informasi Kesehatan, STIKes Panti Waluya Malang, Malang, Jawa Timur, Indonesia \\ Corresponding author : Rea Ariyanti \\ E-mail : ariantirea@gmail.com
}

Diterima 08 Juni 2021, Direvisi 21 Juni 2021, Disetujui 24 Juni 2021

\begin{abstract}
ABSTRAK
Osteoarthritis adalah salah satu penyakit degeneratif yang paling sering mengenai lansia. Penyakit ini hampir $70 \%$ dialami oleh mereka yang berusia diatas 50 tahun, dan menyebabkan kegagalan fungsi yang dapat mengurangi kualitas hidup manusia seperti terhambatnya ruang gerak penderita, penurunan kemampuan kerja, nyeri hebat dan cacat. Sebanyak $80 \%$ penderita mengalami keterbatasan dalam bergerak, dan sisanya bahkan tidak dapat melakukan kegiatan sehari-hari. Berdasarkan studi pendahuluan yang dilakukan di Kelurahan Karang Anyar, Kecamatan Tarakan Barat, Kota Tarakan menunjukkan bahwa masih banyaknya kader kesehatan yang belum mengetahui upaya swamedikasi penyakit osteoarthritis pada lansia. Selain itu diketahui pula Mayoritas pendidikan formal yang ditempuh oleh penduduk di Kelurahan Karang Anyar adalah SLTA (34,6\%), diikuti dengan SD (21,9\%), SLTP $(20,8 \%)$, dan PT $(5,7 \%)$, sisanya belum sekolah/belum tamat SD (17\%). Program kemitraan ini bertujuan untuk meningkatkan pemahaman kader kesehatan terhadap upaya swamedikasi penyakit osteoarthritis, sehingga dengan adanya peningkatan pemahaman diharapkan para lansia dan kader dapat melakukan upaya pengobatan secara mandiri penyakit osteoartritis. Kegiatan ini meliputi survei awal, pendidikan kesehatan melalui pemberian materi dan video pembelajaran, serta melaksanakan diskusi interaktif. Hasil dari kegiatan kemitraan ini adalah adanya peningkatan pemahaman kader kesehatan terkait upaya swamedikasi penyakit osteoarthritis pada lansia di Kelurahan Karang Anyar, Kecamatan Tarakan Barat, Kota Tarakan yang dibuktikan dengan adanya peningkatan nilai saat pretest sebesar 62,00 dan meningkat menjadi 86,00 saat post-test.
\end{abstract}

Kata kunci: edukasi kesehatan; lansia; osteoarthritis; swamedikasi.

\begin{abstract}
Osteoarthritis is one of the most common degenerative diseases affecting the elderly. This disease is almost $70 \%$ experienced by those aged over 50 years, and causes malfunctions that can reduce the quality of human life such as obstruction of the patient's range of motion, decreased ability to work, severe pain, and disability. As many as $80 \%$ of patients experience limitations in moving, and the rest cannot even carry out daily activities. Based on a preliminary study conducted in Kelurahan Karang Anyar, Kecamatan Tarakan Barat, Kota Tarakan, it shows that there are still many health cadres who do not know about self-medication efforts for osteoarthritis in the elderly. In ad dition, it is also known that the majority of formal education taken by residents in Kelurahan Karang Anyar is Senior High school (34.6\%), followed by Elementary School (21.9\%), Junior High School $(20.8 \%)$ and PT $(5.7 \%)$, the rest have not attended school / have not finished elementary school (17\%). This partnership program aims to increase the understanding of health cadres towards self-medication efforts for osteoarthritis so that with an increased understanding, it is $\mathrm{h}$ oped that the elderly and cadres can make efforts to treat osteoarthritis independently. These activities include initial surveys, health education through the provision of learning materials and videos, as well as conducting interactive discussions. The result of this partnership activity is an increase in the understanding of health cadres regarding self-medication efforts for osteoarthritis in the elderly in Kelurahan Karang Anyar, Kecamatan Tarakan Barat, Kota Tarakan as evidenced by an increase in the pre-test score of 54.00 and increased to 86.00 when posttest.
\end{abstract}

Keywords: health education; elderly; osteoarthritis; self-medication.

\section{PENDAHULUAN}

Adanya Pandemi COVID-19 yang

sedang melanda Indonesia turut memberikan dampak bagi suatu desa di berbagai daerah. Covid 19 bukan hanya merupakan suatu wabah biasa, melainkan suatu pandemi. WHO (World 
Health Organization) sebagai organisasi kesehatan dunia mengemukakan untuk menghentikan penyebaran pandemi covid 19 harus ada titik dimana kita bisa melakukan lockdown atau tidak, akan tetapi hal ini masih bersifat debatable, yaitu menimbulkan pro dan kontra. Melihat angka-angka yang kian hari terus mengalami peningkatan, tentu akan menimbulkan kecemasan dan kekhawatiran, khususnya bagi masyarakat Indonesia. Adanya kebijakan dari pemerintah juga turut memberikan dampak bagi masyarakat, bukan hanya dari aspek ekonomi, melainkan juga dari aspek kesehatan.

Kurangnya akses masyarakat terhadap pelayanan kesehatan, menyebabkan kurang nya kontrol terhadap keadaan penyakitnya khususnya pada lansia.

Lansia atau lanjut usia adalah seseorang yang mencapat usia 60 tahun keatas (Kementerian Kesehatan RI, 2019). Proses menua merupakan proses dimana terjadinya penurunan fungsi organ dan penurunan perkembangan fisik yang tidak dapat dihindari. Jumlah lansia dari tahun ke tahun terus bertambah seiring dengan meningkatnya jumlah harapan hidup. Proporsi lanjut usia di dunia menunjukkan peningkatan setiap tahunnya. Saat ini jumlah penduduk lansia di dunia diperkirakan mencapai 500 juta dan pada tahun 2025 diprediksi akan mencapai 1,2 miliar. Data dari Survei Sosial Ekonomi Nasional tahun 2016 menunjukkan bahwa jumlah lansia di Indonesa mencapai 22,4 juta jiwa atau 8,69\% dari jumlah penduduk (Kementerian Kesehatan $\mathrm{RI}, 2014)$.

Osteoarthritis (OA) adalah penyakit rematik yang paling sering mengenai lansia akibat gangguan metabolisme yang diikuti oleh beberapa perubahan pada sistem muskuloskeletal pada lansia. Penyakit OA masuk kedalam sepuluh besar penyakit di Kota Tarakan khusunya di Kecamatan Tarakan Barat (Dinas Kesehatan Kota Tarakan, 2014). Dimana, sepuluh besar penyakit tersebut ratarata selalu mengalami peningkatan. OA merupakan penyakit degeneratif pada persendian yang melibatkan kartilago, lapisan sendi, ligamen, dan tulang sehingga dapat menyebabkan nyeri dan kekakuan pada sendi (Center for Disease Control and Prevention, 2014).

OA sampai dengan saat ini masih merupakan masalah kesehatan utama di dunia. World Health Organization (WHO) menyatakan bahwa OA merupakan salah satu penyebab utama kegagalan fungsi yang mengurangi kualitas hidup manusia di dunia seperti terhambatnya ruang gerak penderita, terjadi penurunan kemampuan kerja, mampu menyebabkan nyeri hebat dan cacat pada penderita, sehingga dapat mengganggu aktivitas sehari-hari. Akibatnya, sebanyak $80 \%$ penderita akan mengalami keterbatasan dalam bergerak dan, sisanya bahkan tidak dapat melakukan kegiatan sehari-hari (WHO, 2016). Prevalensi OA di Asia diperkirakan akan meningkat sebanyak dua kali lipat dari $6,8 \%$ pada tahun 2008, menjadi $16,2 \%$ pada tahun 2040. Kementerian Kesehatan RI (2012), memetakan jumlah penderita $\mathrm{OA}$, hasilnya sekitar lebih dari $11,5 \%$ orang Indonesia menderita OA. Artinya pada setiap 10 penduduk Indonesia terdapat 1 orang penderita OA (Prieharti dan Mumpuni, 2017). Di Indonesia, angka OA masih cukup tinggi yaitu mencapai 36,5 juta orang, dimana prevalensi terbesar terjadi pada usia lebih dari 75 tahun yaitu sebesar $58,8 \%$, diikuti usia $65-74$ tahun sebesar $51,9 \%$, usia 55-64 tahun sebesar $45,0 \%$, dan usia 45-54 tahun sebesar 37,2\%. Sedangkan berdasarkan data dari RISKESDAS (2013) dijetahui bahwa angka kejadian OA di Indonesia banyak terjadi pada perempuan yaitu $27,5 \%$ dan laki-laki yaitu 21,8\% (Kemenkes RI, 2014).

Penyakit $O A$ ini bersifat multifaktorial yang disebabkan oleh berbagai faktor risiko seperti lanjut usia, obesitas, trauma pada sendi, kelainan genetik pada tulang rawan sendi dan tekanan berlebih pada sendi yang disebabkan oleh olahraga (Tika dan Aryana, 2018). Gejala utama yang paling umum dirasakan penderita OA adalah nyeri dan kekakuan pada sendi. Nyeri sendi dapat terjadi ketika aktifitas terlalu berlebihan. Kekakuan pada sendi dikarenakan tidak adanya pergerakan atau aktifitas pada presendian, umumnya timbul di pagi hari ketika baru bangun tidur atau setelah beristirahat di siang hari. Sendi juga dapat mengalami kemerahan, hangat disertai dengan nyeri tekan kemudian terdapat rasa kaku, imobilitas dan deformitas. Apabila terjainya pembentukan osteofit pada sendi tangan atau sendi kaki bisa menyebbakan pembengkaka atau deformitas sendi yang dapat membatasi ruang gerak penderita, dapat mengganggu dan mempengaruhi pada kesejahteraan fisik. Selain itu, OA dapat memiliki dampak mendalam pada setiap aspek kehidupan seseorang dan dapat menyebabkan kecacatan jika tidak diobati dengan benar (Ignatavicius dan Workman, 2015).

Kelurahan Karang Anyar merupakan salah satu kelurahan di Kecamatam Tarakan Barat, Kota Tarakan, Provinsi Kalimantan Utara. Pendidikan akhir yang dimiliki penduduk di kelurahan karang anyar pantai bervariasi. Mayoritas pendidikan formal yang ditempuh oleh penduduk di Kelurahan Karang Anyar 
Pantai adalah SLTA (34,6\%), diikuti dengan SD $(21,9 \%)$, SLTP $(20,8 \%)$, dan PT $(5,7 \%)$, sisanya belum sekolah/belum tamat SD $(17 \%)$ (Dinas Kesehatan Kota Tarakan, 2014). Pemerintah Kota Tarakan telah melakukan upaya pembangunan kesehatan dalam rangka pemerataan pelayanan kesehatan kepada masyarakat. Pembangunan di bidang kesehatan bertujuan untuk memberikan pelayanan kesehatan secara mudah, murah, dan merata. Salah satu upaya yang dilakukan adalah dengan menyediakan 1 Rumah sakit dan 1 Puskesmas di Kecamatan Tarakan Barat. Namun, dengan adanya pandemi COVID 19 turut memberikan dampak bagi masyarakat di Kelurahan Karang Anyar, khususnya pada lansia dimana salah satu dampak yang cukup dirasakan adalah terhambatnya akses warga untuk mendapatkan layanan fasilitas kesehatan.

Kader Kesehatan merupakan jajaran pertama dalam menjangkau masyarakat, ketika tenaga kesehatan tidak ada atau ketika masyarakat sulit mendapatkan akses ke tenaga kesehatan. Kader kesehatan dapat menjadi perpanjangan tangan dalam meningkatkan pemahaman masyarakat tentang status kesehatannya. Selain itu, kader kesehatan juga merupakan jajaran terdepan dalam mentransfer pengetahuan, pemahaman dan keterampilan dalam menangani berbagai macam penyakit degeneratif khususnya osteoarthritis, sehingga kader menjadi sangat penting untuk mendapatkan pemahaman tentang penyakit osteoarthritis itu sendiri dan berkenaan dengan upaya swamedikasi penyakit osteoarthritis khususnya pada lansia. Program kemitraan ini bertujuan untuk meningkatkan pemahaman kader kesehatan terhadap upaya swamedikasi penyakit osteoarthritis, sehingga dengan adanya peningkatan pemahaman diharapkan para lansia dan kader dapat melakukan upaya pengobatan secara mandiri penyakit osteoartritis.

\section{METODE}

Metode pelaksanaan yang diterapkan untuk mencapai tujuan dari program kemitraan ini adalah dengan memberikan penyuluhan tentang osteoartritis pada lansia dan uupaya swamedikasi penyakit ostaoertirits, memberikan video pembelajaran, dan dilanjutkan dengan diskusi inetarktif. Penyuluhan diberikan oleh 3 pemateri kepada 24 kader kesehatan yang ada di Kelurahan Karang Anyar, Kecamatan Tarakan Barat, Kota Tarakan. Kegiatan dilaksanakan pada pagi hari pukul 10.00 WIB sampai dengan 13.00 WIB. Adapun materi yang diberikan adalah materi terkait penyakit osteoarthritis dan upaya swamedikasi penyakit osteoarthritis pada lansia.
Selain memaparkan materi yang diberikan pada saat penyuluhan, pemateri juga membagikan media bantu seperti video pembelajaran pada lansia dan para kader.

Kegiatan ini dilakukan untuk meningkatkan pemahaman kader terkait upaya swamedikasi penyakit osteoarthritis pada lansia. Untuk menilai tingkat pemahaman kader terkait penyakit osteoarthritis khususnya upaya swamedikasi penyakit osteoarthritis pada lansia, maka sebelum diberikan penyuluhan, para kader akan dilakukan pretest dan di akhir penyuluhan akan dilakukan posttest. Secara garis besar, pertanyaan yang dicantumkan pada pre dan posttest adalah pertanyaan seputar osteoarthritis seperti definisi osteoarthritis, faktor risiko osteoartritis, penyebab osteoarthritis, dampak osteoarthritis, upaya swamedikasi penyakit osteoarthritis.

\section{HASIL DAN PEMBAHASAN}

Pelaksanaan kegiatan penyuluhan dilaksanakan sebanyak 2 (dua) kali yaitu pada tanggal 22 dan 29 Agustus 2020 dengan metode ceramah dan diskusi inetraktif bersama dengan 24 kader kesehatan lansia. Kegiatan Penyuluhan I disampaikan oleh 2 pemateri yaitu Dosen dari Program Studi D-IV Manajemen Informasi Kesehatan sebagai berikut: Penyakit osteoarthritis dan upaya pencegahan penyakit osteoarthritis pada lansia. Sedangkan, kegiatan penyuluhan II disampaikan oleh 1 pemateri dari dosen Prodi S1 Farmasi dengan materi Upaya Swamedikasi Penyakit Hipertensi pada lansia.

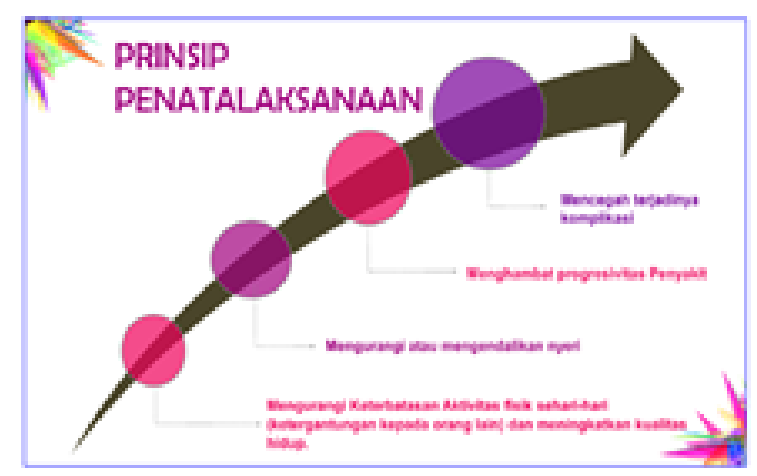

Gambar 1. Pemaparan Materi Osteoarhtririts 


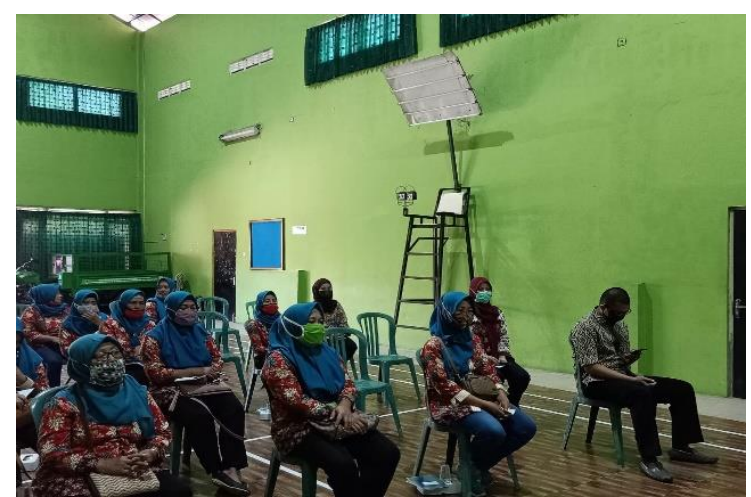

Gambar 2. Pemberian Edukasi Kesehatan

Dari hasil analisa data yang dilakukan pada nilai pretest dan postest para kader kesehatan, diketahui bahwa telah terjadi peningkatan atau kenaikan tingkat pemahaman terkait swamedikasi penyakit osteoarthritis pada lansia, hal ini dapat dilihat pada Tabel 1, dimana sebelum diberikan penyuluhan, ratarata nilai pre test sebesar 62,00 dan setelah diberikan penyuluhan terjadi peningkatan nilai post test menjadi 86,00 .

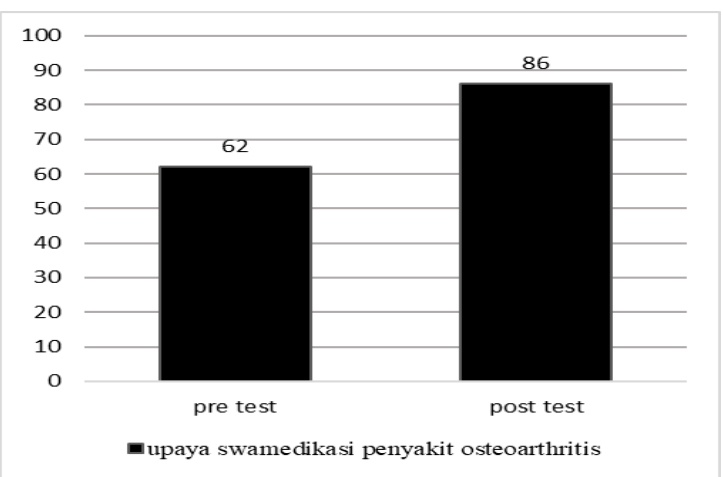

Gambar 3. Hasil Pre dan Post test

Penyuluhan kesehatan adalah kegiatan pendidikan kesehatan, yang dilakukan dengan menyebarkan pesan, menanamkan keyakinan, sehingga masyarakat tidak saja sadar, tahu dan mengerti, tetapi juga mau dan bisa melakukan suatu anjuran yang ada hubungannya dengan kesehatan dengan tujuan tercapainya perubahan perilaku individu, keluarga dan masyarakat dalam membina dan memelihara perilaku sehat dan lingkungan sehat, serta berperan aktif dalam upaya mewujudkan derajat kesehatan yang optimal (Haryani dkk dalam Martahayu, 2021).

Sebagian besar pengetahuan manusia diperoleh melalui mata dan telinga seperti poster, majalah, atau sumber informasi yang berbentuk tulisan dan informasi yang berbentuk suara seperti seminar, penyuluhan, atau pembicaraan dari orang lain melalui percakapan sehari-hari. Penyuluhan yang dilakukan dengan metode yang tepat dapat menarik perhatian serta mempermudah pemahaman terhadap penyuluhan yang diberikan. Dengan diberikannya penyuluhan, maka responden yang semula belum mengetahui menjadi mengetahui dan memahami (Muthia, 2016).

Kurangnya akses masyarakat terhadap pelayanan kesehatan, menyebabkan kurangnya kontrol terhadap keadaan penyakitnya khususnya pada lansia. Dengan adanya edukasi kesehatan yang diberikan kepada para kader, diharapkan adanya peningkatan pengetahuan yang didapatkan oleh kader kesehatan turut membantu para lansia dalam upaya swamedikasi penyakit osteoartritis.

Posyandu merupakan salah satu bentuk pemberdayaan masyarakat yang dapat menjembatani antara tenaga kesehatan dengan masyarakat. Kader kesehatan di suatu desa merupakan jajaran pertama dalam menjangkau masyarakat, ketika tenaga kesehatan tidak ada atau ketika masyarakat sulit mendapatkan akses ke tenaga kesehatan. Kader kesehatan dapat menjadi perpanjangan tangan dalam meningkatkan pemahaman masyarakat tentang status kesehatannya, terutama pada lansia. Selain itu, kader kesehatan juga merupakan jajaran terdepan dalam mentransfer pengetahuan, pemahaman, dan keterampilan dalam menangani berbagai penyakyt degenratif pada lanisa, sehingga peran kader kesehatan di suatu desa menjadi sangat penting untuk mendapatkan pengetahuan tentang penyakit osteoarthritis itu sendiri dan berkenaan dengan upaya swamedika penyakit osteoarhtritis pada lansia. Dengan adanya pemberdayaan kepada kader kesehatan terkait upaya swamedikasi penyakit osteoarthritis khususnya pada lansia dapat tertangani dengan baik.

\section{SIMPULAN DAN SARAN}

Edukasi kepada kader kesehatan tentang upaya swamedikasi penyakit osteoarthritis pada lansia telah terlaksana dengan baik. Dari hasil pre dan post test, maka diketahui terdapat peningkatan yang signifikan pada pengetahuan para kader kesehatan dalam upaya swamedikasi penyakit osteoarthritis pada lansia. Kegiatan ini perlu dilakukan sebagai upaya meningkatkan kesadaran, kepedulian dan mendorong keterlibatan peran kader dalam upaya swamedikasi penyakit ostearthritis pada lansia.

\section{UCAPAN TERIMAKASIH}

Tim pengabdi mengucapkan terimakasih kepada Sekolah Tinggi IImu Kesehatan Panti Waluya Malangv yang telah mendanai kegiatan pengabdian masyarakat 
hingga selesai.

\section{DAFTAR RUJUKAN}

Aris, M. (2015). The Relations Between Obesity and Osteoarthritis Knee in Elderly Patients. J Majority, 4(5), 110-116.

Center for Disease Control and Prevention (CDC). (2014). Osteoarthritis. Diakses pada tanggal 26 Maret 2020 dari

http://www.cdc.gov/arthritis/basics/os teoarthritis.html

Ignativicius, S., Workman. (2015). MedicalSurgical Nursing: Patient-Centered Collaborative Care (8th ed). St.Louis, Missouri: Elsevier

Kementerian Kesehatan RI. (2014). Profil Kesehatan Indonesia Tahun 2013. Diakses pada tanggal 26 Maret 2020 dari http://www.depkes.go.id

Kementerian Kesehatan RI. (2014). Riset Kesehata Dasar (Riskesdas): Penyakit Tidak Menular:Sendi Rematik Encok. Hal 94. Badan Penelitian dan Pengembangan Kesehatan. Kementerian Kesehatan RI: Jakarta

Kementerian Kesehatan RI. (2016). Menepis Serangan Osteoartritis. Diakses pada tanggal 26 Maret 2020 dari http://www.p2ptm.kemkes.go.id/doku men-p2ptm/

Kementerian Kesehatan RI. (2019). Situasi Lanjut Usia (LANSIA) di Indonesia. Jakarta: Pusat Data dan Informasi Kementerian Kesehatan RI.

Kholifah, S (2016). Keperawatan Gerontik. Jakarta: Kementerian Keseharan Republik Indonesia: Pusat Pendidikan Sumber Daya Manusia Kesehatan Badang Pengembangan dan Pemberdayaan Sumber Daya Manusia Kesehatan.

Martahayu, Vika., Yuanita. (2021). Penyuluhan Kesehatan di Masa Pandemi dan New Normal Menggunakan Media Edukatif Berbasis Aduio Visual. Vol 4 (2), April 2021. SELAPARANG: Jurnal pengabdian Masyarakat Berkemajuan

Meiner, Sue E. (2011). Gerontology Nursing, Fourth Edition. United States of America: Elsevier Mosby

Nisak R, Maimunah S, Admadi T. (2018). Upay Pemberdayaan Masyarakat Melalui Deteksi Dini Pengendalian Penyakit Degeneratif pada Lansia di Dusun Karang Pucang, Desa Ngancar, Kecamatan Pitu, Wilayah Kerja Puskesmas Pitu, Kabupaten Ngawi.
Ngawi: Akademi Keperawatan Pemerintah Kabupaten Ngawi

Prieharti dan Mumpuni, Y. (2017). Deteksi: Osteoartritis vs Osteoporosis Perbedaan, Seluk Beluk dan Penanganan. Yogyakarta: Rapha Publishing

Rahmawati, R., Kusuma FHD., Widiani, E. (2012). Analisis Faktor Risiko Kejadian Osteoartritis (Sendi Lutut) pada pasien Lanjut Usia, Journal of Ners Community. Vol 3:2, 151-158.

Susilawati, L., Tirtayasa, K., dan Lesmana, SI. (2015). Latihan Closed Kinetic Chain Lebih baik Daripada Open Kinetic Chain untuk Meningkatkan Kemampuan Fungsional pada Osteoarthritis Lutut setelah Pemberian Micro Wave Diatherny (MWD) dan Transcutaneus Electrical Nerve Stimulation. Vol 3(10, 26-34

Tika, Pradnya dan Aryana, W. (2018). Hubungan Antara Tingkat Nyeri Berdasarkan Numerical Rating Scale dengan Intensitas Osteoartritis Secara Radiologi Menurut KallgrenLawrence Grading System Pada Penderita Osteoartritis Lutut di Rumah Sakit Sanglah. E-Journal Medika. Vol 7(6), Juni 2018. Hal 1-8

WHO. (2016). Osteoarthritis (online). Diakses pada tanggal 26 Maret 2020 dari http://www.who.int/medicines/areas/p riority_medicines/BP6_12Osteo.pdf). 